\title{
ЛАПАРОСКОПІЧНА КОРЕКЦІЯ ГІНЕКОЛОГІЧНОЇ ПАТОЛОГІЇ ПІД ЧАС ГЕРНІОПЛАСТИКИ
}

\author{
Лапароскопічна корекція гінекологічної патології \\ під час герніопластики

\section{К. Ю. Пархоменко} \\ Харківський національний медичний університет
}

Резюме. Симультанні операції із приводу хірургічної та гінекологічної патологій виконують значно рідше, ніж зустрічаються ці поєднані захворювання.

Мета дослідження - вивчити структуру та результати симультанних операцій у пацієнток із вентральними грижами у поєднанні з гінекологічною патологією.

Матеріали і методи. Вивчено особливості оперативних втручань та їх безпосередні результати у 46 жінок із вентральними грижами у поєднанні з гінекологічною патологією.

Результати. Встановлено, що пролонгація операціі та карбоксиперитонеуму при лапароскопічній герніопластиці була не критичною та зумовлена виключно додатковим втручанням. При відкритих герніопластиках пролонгації карбоксиперитонеуму не було. У хворих на вентральні грижі можна здійснити більшість гінекологічних втручань, які можливі із застосуванням лапароскопічного доступу. Здійснення гінекологічного етапу операції не впливає на особливості герніопластики та на розвиток ускладнень та тривалість стаціонарного лікування.

Висновки. Симультанні операції з приводу гриж черевної стінки та гінекологічної патології вважаємо доцільними у хворих із поєднаною патологією в повсякденній практиці.

Ключові слова: доброякісні гінекологічні захворювання; герніопластика; пангістеректомія за I типом; аднексектомія; безпосередній результат.

\section{ВСТУП}

Поєднана (в англомовній літературі коморбідна або мультиморбідна патологія) в останні роки привертає все більшу увагу лікарів різного просрілю. У зв' язку зі старінням населення світу та значним розширенням можливостей сучасних методів діагностики, ізольовані захворювання $€$ швидше винятком. При ретельному обстеженні у більшості пацієнтів виявляють те чи інше супутнє захворювання $[1,2]$.
Laparoscopic correction of gynecological pathology in hernioplasty

K. Yu. Parkhomenko

Kharkiv National Medical University

e-mail:pku70@ukr.net

Summary. Simultaneous operations on surgical and gynecological pathology are performed much less often than these combined diseases.

The aim of the study - to investigate the structure and results of simultaneous operations in patients with ventral hernias in combination with gynecological pathology.

Materials and Methods. The features of surgical interventions and their immediate results were studied in 46 women with ventral hernias in combination with gynecological pathology.

Results. It was found that the prolongation of the operation and carboxyperitoneum in laparoscopic hernioplasty was not critical and was solely due to additional intervention. In open hernioplasty, there was no prolongation of carboxyperitoneum. In patients with ventral hernia, most of the gynecological interventions, that are possible with the laparoscopic approach, can be performed. The implementation of the gynecological stage of the operation does not affect the features of hernioplasty, the development of complications and the duration of inpatient treatment.

Conclusions. Simultaneous operations on abdominal wall hernias and gynecological pathology are considered appropriate in patients with combined pathology in everyday practice.

Key words: benign gynecological diseases; hernioplasty; panhysterectomy type I; adnexectomy; immediate result.

Для хірургів ця проблема має подвійне значення. 3 одного боку, наявність загальносоматичних системних захворювань, які є фрактором ризику несприятливих подій під час операції та у післяопераційному періоді [3], з іншого боку - це наявність двох та більше захворювань, що вимагають хірургічного лікування. Вирішення цього аспекту проблеми поєднаної патології можливе шляхом етапного поступового лікування або шляхом симультанної 
операції - одночасного усунення захворювань протягом одного втручання. Останній напрямок стає все більш привабливим у зв'язку з упровадження в рутинну клінічну практику відеолапароскопічних технологій [4]. Зокрема, мініінвазивний лапароскопічний доступ застосовується для симультанного хірургічного лікування гінекологічної та хірургічної патології [5]. Такій підхід є дуже доцільним у хворих на вентральні грижі.

Метою дослідження було вивчити структуру та результати симультанних операцій у пацієнток із вентральними грижами у поєднанні 3 гінекологічною патологією.

\section{МАТЕРІАЛИ I МЕТОДИ}

Протягом 2016-2019 рр. у хірургічних відділеннях Державного закладу «Спеціалізована медико-санітарна частина № 13» МО3 України та Комунального некомерційного підприємства Харківської обласної ради «Обласна клінічна лікарня» симультанні операції з приводу вентральних гриж та доброякісної гінекологічної патології здійснено 46 жінкам. Середній вік пацієнток складав $(48,6 \pm 9,2)$ року $(95 \%$ ДІ 45,9; 51,4).

У 25 (54 \%) діагностовано пупкову грижу, в 5 (11 \%) - параумбілікальну, у 8 (17 \%) - післяопераційну грижу параумбілікальної локалізації та у 8 (17 \%) - пахову грижу. Доброякісні захворювання матки виявлено у 28 (61 \%) жінок, з них у 13 пролапс матки II-III ст., у 18 (39 \%) - доброякісні захворювання придатків матки. У 10 (22 \%) діагностовано ожиріння I-ІІ ст.

Обсяг оперативних втручань був наступним (табл. 1).

У пацієнток із паховими грижами створення карбоксиперитонеуму та введення основного 10-міліметрового троакара виконувалось із косметичною метою в ділянку пупка (по середній лінії на 2-3 см нижче пупка). В мезогастральній ділянці зліва по середньо-ключичній лінії вводили 5-міліметровий та справа 10-міліметровий або 11-мілі- метровий троакар за типом триангуляції. Після ревізії черевної порожнини здійснювали мобілізацію патологічно змінених додатків матки та пересічення маткової труби в ділянці кута матки за допомогою електрокоагуляційного апарату «LigaSure». Для пангістеректомії (ПГЕ) за I типом мобілізацію матки здійснювали наступним способом [6]. Через центральний троакар в черевну порожнину вводили біполярний електрокоагулятор, на який подавали високочастотний змінний струм апаратом «LigaSure», за його допомогою здійснювали відділення маткового кінця зв'язкового апарату від черевного з одночасним запаюванням зв'язок куксою. Це забезпечувало надійний гемостаз та пришвидшувало здійснення операції порівняно з лігатурним методом. Куксу піхви при ПГЕ фоормували й ушивали наступним чином. Для цього на кінці нитки «Полісорб 3-0» 12 см зав'язували вузлик із петлею, довжина якої становить 5 мм і залишковою довжиною 3 см. Перший шов накладали через усі шари на лівий край вагінальної рани до моменту фріксації вузликом. Голку з ниткою протягували крізь петельку. Проводили зшивання передньої та задньої стінок піхви простим обвивним швом у напрямку зліва на право. Далі над вже ушитою вагінальною раною в напрямку справа наліво тією ж ниткою проводили зашивання листків очеревини (перитонізацію). Обидва кінці нитки зустрічались у лівому куті рани, які зв'язували між собою [7]. Наступним етапом здійснювали ТАРР-пластику із застосуванням сітчастого трансплантату 3DMAX Light Mesh або ProGrip Laparoscopic Self-Fixating Mesh розмірами 7,9×13,4 см, яку герніостеплером фріксували до окістя лобкової кістки, пахової зв' язки та м'язового шару передньої черевної стінки. Цілість очеревини відновлювали клаптем її за допомогою степлера або зварювальним апаратом «Свармед» ЕВ3 300М.

У випадках невеликих умбілікальних та параумбілікальних гриж (дефект апоневрозу менше 2 см) створення доступу для основного троакара здійснювали одразу нижче грижового дефекту, та

Таблиця 1. Обсяг оперативних втручань у пацієнток із вентральними грижами у поєднанні з генітальною патологією

\begin{tabular}{l|c|c|c}
\hline \multirow{2}{*}{\multicolumn{1}{c|}{ Метод герніопластики }} & \multicolumn{2}{|c|}{ Гінекологічна операція } & \multirow{2}{*}{ Разом } \\
\cline { 2 - 4 } & $\begin{array}{c}\text { екстирпація матки } \\
\text { з придатками }\end{array}$ & операція на придатках матки & $8(100 \%)$ \\
\hline ЛГП ТАРР & $5(63 \%)$ & $3(37 \%)$ & $28(100 \%)$ \\
\hline ЛГП ІРОМ & $17(61 \%)$ & $11(39 \%)$ & $6(100 \%)$ \\
Відкрита пластика: & $4(67 \%)$ & $2(33 \% 0$ & $2(100 \%)$ \\
- sub-Іау & $2(100 \%)$ & - & $2(100 \%)$ \\
- on-Іау & - & $2(100 \%)$ & $46(100 \%)$ \\
\hline Мейо & $28(61 \%)$ & $18(39 \%)$ & \\
\hline Разом & & & \\
\hline
\end{tabular}

Примітка. ЛгП ТАРP - лапароскопічна трансабдомінальна преперитонеальна герніопластика (TAPP - Trans Abdominal Pre-Peritoneal ТАРP); ЛГП ІРОМ - лапароскопічна інтраабдомінальна пластика (IPOM - intraperitoneal on-lay mesh).

ISSN 2706-6282(print)

ISSN 2706-6290(online)
Вісник медичних і біологічних досліджень Bulletin of Medical and Biological Research
$4(6), 2020$ 
на заключному етапі операції виконували відкриту сітчасту (sub-lay або on-lay методом) герніопласо тику або шовну пластику власними тканинами за Мейо. При наявності дефекту апоневрозу більше 2 см основний троакар вводили через розріз шкіри на межі середньої та нижньої третин лінії від груднини до пупка та додатково встановлювали 5-міліметровий троакар у здухвинній ділянці зліва по середньо-ключичній лінії. Оптику переміщали в 10-міліметровий троакар, який встановили в лівому мезогастрії. Герніопластику здійснювали композитним сітчастим трансплантатом на основі технології Sepra, котрий герніостеплером фріксували по периметру та в ділянці грижових воріт.

Крім цього, в 4 (9\%) пацієнток у зв'язку 3 холецистолітіазом здійснено лапароскопічну холецистектомію (ЛХЕ), у 12 (26 \%) випадках у зв'язку зі спайками додатково здійснено адгезіоліз. При цьому встановлювали додаткові троакари: 5-міліметровий в лівому підпечінковому просторі й робочий 10-міліметровий у ділянці мечоподібного відростка по середній лінії. Оптику переміщували в центральний троакар. Хвора переміщувалась у положення анти-Тренделенбург з поворотом вліво. Екран лапароскопічної стійки переміщувався в головну частину справа.

У всіх пацієнтів для профрілактики спайкоутворення після завершення операції шляхом пункції черевної порожнини в лівій клубовій ділянці в ділянці малого таза вводили 5 г гіамакс біо в 100 мл 0,9 \% розчину натрію хлориду [8].

Усі хворі оперовані в плановому порядку після здійснення комплексу обов' язкових та додаткових загальноклінічних, лабораторних та інструментальних досліджень згідно з існуючими настановами. Вивчено структуру та результати оперативних втручань з приводу основного захворювання та симультанних операцій.

Отримані результати обробляли за допомогою пакета статистичних програм PSSP із застосуванням частотного аналізу. Різницю між групами вважали достовірно при p<0,05. Результати наведено у вигляді абсолютна кількість (\%) для якісних показників та $\mathrm{M} \pm \mathrm{SD}$ (середнє та стандартне відхилення середнього) - для кількісних показників.

\section{РЕЗУЛЬТАТИ Й ОБГОВОРЕННЯ}

Усі оперативні втручання з приводу гінекологічної патології здійснено лапароскопічним доступом на першому етапі хірургічного втручання. Спосіб герніопластики залежав вид локалізації грижі. При пахових грижах у всіх випадках застосовували лапароскопічну протезуючу передочеревинну герніопластику. При грижах умбілікальної та параумбілікальної локалізації вибір методу герніопластики залежав від розміру грижових воріт. При невеликих пупкових грижах застосовано шовну пластику власними тканинами за Мейо, при грижах середньої величини - ненатяжна протезуюча герніопластика sub-lay- (ретромускулярно) або onlay- (над апоневрозом) методом. При великих та післяопераційних грижах застосовано інтраперитонеальний (IPOM) метод сітчастої герніопластиғ ки. Метод герніопластики планували до операції та відповідно плану операції обирали місце введення основного та додаткових троакарів.

Вибір методу пластики пахових гриж при симультанній гінекологічній операції зумовлено виключно лапароскопічним доступом, що відповідає даним інших авторів, разом 3 тим, як при пупкових грижах найчастіше здійснюється відкрита алопластика [6].

В якості негативних особливостей симультанних лапароскопічних втручань найчастіше згадують збільшення тривалості операції із небезпекою тривалого впливу напруженого карбоксиперитонеуму. При відкритих методах герніопластики тривалість карбоксиперитонеуму не збільшувалась, тому що кінцевий етап виконували після повної десуфрляції черевної порожнини. Пролонгація операції та карбоксиперитонеуму при лапароскопічній герніопластиці була не критичною та була зумовлена виключно додатковим втручанням (табл. 2).

Загальна тривалість операції включала навчальний етап (створення доступу та карбоксиперитонеуму, ревізія черевної порожнини) - у середньому (12士4) хв. Крім цього, в трьох випадках тривалість оперативного втручання збільшена за

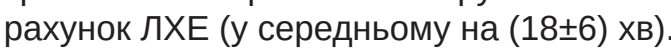

Загальних ускладнень після операції не було, серед місцевих - 2 випадки сероми в ділянці піс-

Таблиця 2. Тривалість симультанної герніопластики та її окремих етапів

\begin{tabular}{l|c|c|c}
\hline \multicolumn{1}{c|}{ Обсяг симультанної операції } & $\begin{array}{c}\text { Тривалість гінекологічного } \\
\text { етапу, хв }\end{array}$ & $\begin{array}{c}\text { Тривалість } \\
\text { герніопластики, хв }\end{array}$ & $28 \pm 9$ \\
\hline ЛГП ТАРР + ПГЕ & $53 \pm 14$ & $26 \pm 8$ & $76 \pm 14$ \\
\hline ЛГП ТАРР + АЕ & $12 \pm 6$ & $19 \pm 10$ & $10 \pm 15$ \\
\hline ЛГП ІРОМ + ПГЕ & $51 \pm 9$ & $18 \pm 1$ & $38 \pm 14$ \\
\hline ЛГП ІРОМ + АЕ & $13 \pm 7$ & 16 \\
\hline
\end{tabular}

Примітка. ЛГП ТАРP - лапароскопічна трансабдомінальна преперитонеальна герніопластика (TAPP - Trans Abdominal Pre-Peritoneal ТАРP); ЛГП ІРОМ - лапароскопічна інтраабдомінальна пластика (IPOM - intraperitoneal on-lay mesh); AE - аднексектомія; ПГЕ - пангістеректомія. 1 - у трьох випадках додатково здійснено лХЕ. 
ляопераційної рани в навколопупковій ділянці; 1 випадок інорільтрату троакарної рани, 1 випадок - тривалої підшкірної емфіземи. У всіх випадках ускладнення були у жінок із надмірною масою. Середня тривалість стаціонарного лікування складала $(5,8 \pm 1,4)$ дня $(95 \%$ ДІ 5,4; 6,2). В трьох випадках збільшення тривалості стаціонарного лікування (8-9 днів) зумовлено рановими ускладненнями.

Як і інші автори [5, 9], ми вважаємо, що симультанні оперативні втручання при вентральних грижах та гінекологічній патології є доцільними, тому що ускладнюють здійснення операції, але позбавляють жінку від необхідності повторних операцій, в окремих випадках в умовах спайкового процесу.

\section{СПИСОК ЛІТЕРАТУРИ}

1. Kuipers S. J. Views of patients with multi-morbidity on what is important for patient-centered care in the primary care setting / S. J. Kuipers, A. P. Nieboer, J. M. Cramm // BMC. Fam. Pract. - 2020. - Vol. 21 (1). - P. 71. - Access mode : https://doi.org/10.1186/s12875-020-01144-7.

2. Ording A. Concepts of comorbidities, multiple morbidities, complications, and their clinical epidemiologic analogs / A. Ording, H. Sorensen // Clin. Epidemiol. 2013. - Vol. 5. - P. 199-203. - Access mode : https:// doi.org/10.2147/CLEP.S45305.

3. Evaluation of high-risk, comorbid patients undergoing open ventral hernia repair with synthetic mesh / D.M.Krpata, J.A. Blatnik, Y.W. Novitsky, M.J. Rosen.//Surgery. -2013. - Vol. 153 (1). - P. 120-125. -Access mode : https:// doi.org/10.1016/j.surg.2012.06.003.

4. Дронова В. Л. Нові підходи до анестезіологічного забезпечення при симультанних операційних втручаннях у жінок із поєднаною гінекологічною та екстрагенітальною хірургічною патологією / В. Л. Дронова // Шпитальна хірургія. - 2015. - № 2. - C. 27-31. - Access mode: https://doi.org/10.11603/2414-4533.2015.2.5227.

5. Лифтинговая лапароскопия в симультанной хирургии / Б. С. Запорожченко, В. В. Колодий, А. А. Горбунов [та ін.] // Клінічна хірургія. - 2017. - № 3. - С. 5-8. - Access mode: https://hirurgiya.com.ua/index.php/journal/ article/view/53.

\section{REFERENCES}

1. Kuipers SJ, Nieboer AP, Cramm JM. Views of patients with multi-morbidity on what is important for patientcentered care in the primary care setting. BMC Fam Pract. 2020;21(1): 71. Available from: https://doi.org/10.1186/ s12875-020-01144-7.

2. Ording A, Sorensen H. Concepts of comorbidities, multiple morbidities, complications, and their clinical epidemiologic analogs. Clin Epidemiol. 2013;5: 199-203. Available from: https://doi.org/10.2147/CLEP.S45305.

3. Krpata DM, Blatnik JA, Novitsky YW, Rosen MJ. Evaluation of high-risk, comorbid patients undergoing open ventral hernia repair with synthetic mesh. Surgery. 2013;153(1): 120-5. Available from: https://doi.org/10.1016/j. surg.2012.06.003.
Перспективним напрямком подальших досліджень $€$ розробка протоколів доопераційного обстеження та хірургічного лікування жінок із коморбідними захворюваннями.

\section{ВИСНОВКИ}

У хворих із вентральними грижами можна здійснити більшість гінекологічних втручань, які можливі із застосуванням лапароскопічного доступу. Здійснення гінекологічного етапу операції не впливає на особливості герніопластики, а збільшення тривалості карбоксиперитонеуму $є$ не критичним та не впливає на розвиток ускладнень та тривалість стаціонарного лікування.

6. Пат. на корисну модель № 114419 Україна, МПК (2017.01) А 61 В 17/42. Спосіб мобілізації матки при ендоскопічних гінекологічних операціях / К. Ю. Пархоменко, Р. В. Павлов винахідники ; заявник та патентовласник Харківська мед. акад. післядипломної освіти. - № u 2016 08933 ; заявл. 19.08.2016 ; опубл. 10.03.2017, Бюл. № 5 (72).

7. Пат. на корисну модель № 114414 Україна, МПк (2017.01) А 61 В 17/34. Спосіб ушивання кукси піхви при екстирпації матки / К. Ю. Пархоменко, Ю. О. Вінник, Р. В. Павлов, К. О. Ключко винахідники ; заявник та патентовласник Харківська мед. акад. післядипломної освіти. - № u 201608921 ; заявл. 19.08.2016 ; опубл. 10.03.2017, Бюл. № 5 (72).

8. Пат. на корисну модель № 114417 Україна, МПК (2017.01) А 61 В 17/34. Спосіб попередження спайкової хвороби після операцій на черевній порожнині / К. Ю. Пархоменко, В.В.Бойко, Р. В. Павлов винахідники ; заявник та патентовласник Харківська мед. акад. післядипломної освіти. - № и 201608926 ; заявл. 19.08.2016 ; опубл. 10.03.2017, Бюл. № 5 (72).

9. Опыт хирургического лечения симультанной патологии у гинекологических больных / А. Н. Шихметов, Л. А. Осин, А. А. Пазычев, А. М. Задикян // Амбулаторная хирургия. - 2018. - № 1-2. - С. 69-70. - Access mode : https://doi.org/10.21518/1995-14772018-1-2-64-71.

4. Dronova VL. [New approaches in anaesthesiological supply of simultaneous operations in females with combined gynecological and extragenital surgical pathology]. Shpytalna khirurhiia. 2015;2: 27-31. Available from: https:// doi.org/10.11603/2414-4533.2015.2.5227. Ukrainian.

5. Zaporozhchenko BS, Kolodiy VV, Gorbunov AA, Zaporozhchenko MB, Muravyev PT, Kholodov IG. [Lifting laparoscopy in simultaneous surgery]. Klinichna khirurhiia. 2017;3: 5-8. Available from: https://hirurgiya.com.ua/index. php/journal/article/view/53. Russian.

6. Pat. Ukraine for utility model No. 114419. MPK (2017.01) A 61 V 17/42. Parkhomenko KYu, Pavlov RV, inventors; Kharkiv Medical Academy of Postgraduate Education, assignee. [Method of mobilization of the uterus
$4(6), 2020$ 
in endoscopic gynecological operations]. No. u 201608933. 2017 Mar 10, Bull. No. 5 (72). Ukrainian.

7. Pat. Ukraine for utility model No. 114414. MPK (2017.01) A 61 V 17/34. Parkhomenko KYu, Vinnyk YuO, Pavlov RV, Klyuchko KO, inventors; Kharkiv Medical Academy of Postgraduate Education, assignee. [Method of suturing the stump of the vagina during uterine extirpation]. No. u 2016 08921; 2017 Mar 10, Bull. No. 5 (72). Ukrainian.

7. Pat. Ukraine for utility model No. 114417. MPK (2017.01) A 61 V 17/34. Parkhomenko KYu, Boyko VV,
Pavlov RV, inventors; Kharkiv Medical Academy of Postgraduate Education, assignee. [Method of prevention of adhesive disease after operations on abdominal cavity]. No. u 2016 08926; 2017 Mar 10, Bull. No. 5 (72). Ukrainian.

8. Shihmetov AN, Osin LA, Pazychev AA, Zadikjan AM. [Stationary replacement technologies in the surgical treatment of simultaneous pathology in gynecological patients]. Ambulatornaya khirurgiya. 2018;1-2: 69-70. Available from: https://doi.org/10.21518/1995-14772018-12-64-71. 